ISSN 2236-0859

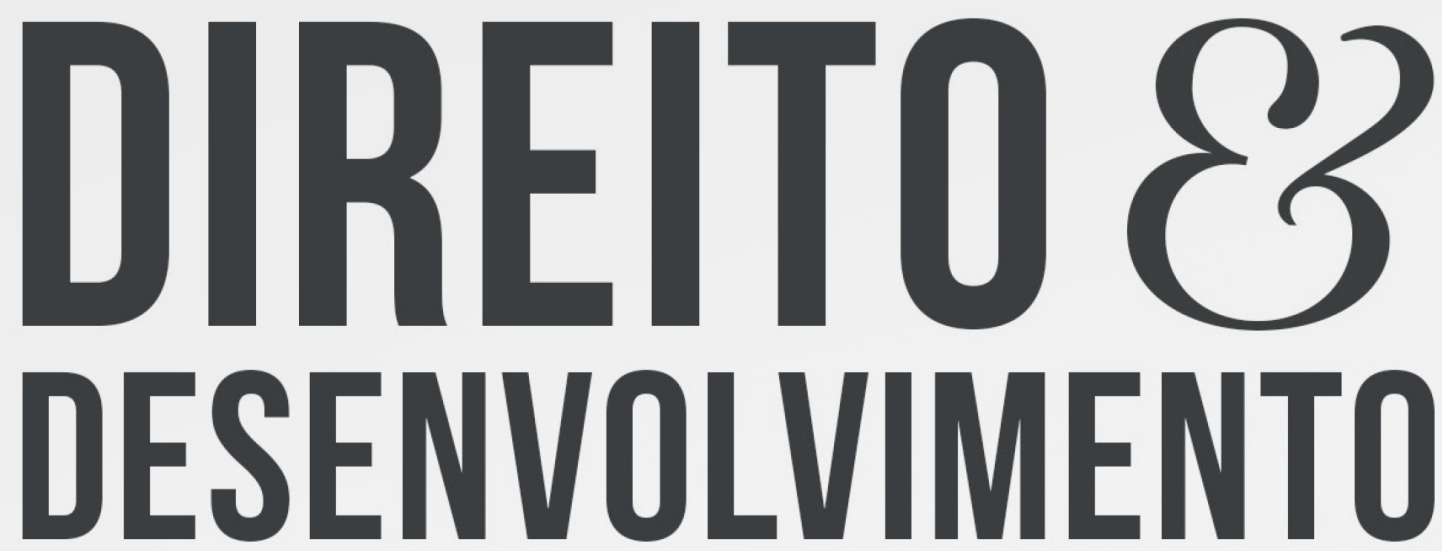

REVISTA DO PROGRAMA DE PÓS-GRADUAÇ̃̃O EM DIREITO MESTRADO EM DIREITO E DESENVOLVIMENTO SUSTENTÁVEL

\title{
UMA RELEITURA OBRIGATÓRIA DO DIREITO DE ASILO E DE REFÚGIO NO CONTEXTODA NOVA LEI DE MIGRAÇÃO
}

\author{
DELLTON RIBEIRO BRASIL \\ TATIANNY KARINY VELOSO GOMES
}




\title{
UMA RELEITURA OBRIGATÓRIA DO DIREITO DE ASILO E DE REFÚGIO NO CONTEXTO DA NOVA LEI DE MIGRAÇÃO
}

\section{A COMPULSORY REREADING OF ASYLUM AND SHELTER RIGHTS IN THE CONTEXT OF THE NEW MIGRATION ACT}

Recebido: 02/02/2019

Aprovado: 01/12/2020
Deilton Ribeiro Brasil ${ }^{1}$

Tatianny Kariny Veloso Gomes ${ }^{2}$

\section{RESUMO:}

O objetivo do presente artigo é analisar a coexistência dos dois sistemas de proteção aos indivíduos, quais sejam asilo e refúgio, bem como as dificuldades de aplicação e dúvidas conceituais, especificamente, em âmbito nacional, onde o dualismo entre os sistemas de proteção se faz presente. Para tanto, recorre-se aos registros históricos de cada um, com o escopo de compreender a natureza jurídica dos institutos, bem como a análise da legislação pertinente, tanto os tratados e convenções internacionais quanto a legislação nacional à luz da nova Lei de Migração. Por meio da pesquisa bibliográfica e documental, com revisão da legislação e doutrina seguindo o método descritivo-dedutivo, os resultados obtidos foram no sentido de se destacar eventuais inovações trazidas pela referida lei aos institutos jurídicos do asilo e refúgio delineando suas semelhanças e diferenças.

Palavras-chave: Direito de asilo. Direito de refúgio. Lei de migração. Dualismo. Inovações.

\begin{abstract}
:
The aim of this article is to analyze the coexistence of the two systems of protection to individuals, such as the right of asylum and access to shelter, as well as the difficulties of application and conceptual doubts, specifically, at the national level, where the dualism between protection systems is present. Therefore, the historical records of each are used, with the purpose of understanding the legal nature of the institutes, as well as the analysis of the relevant legislation, both international treaties and conventions and national legislation in light of the new Migration Act. Through bibliographic and documentary research, with a review of legislation

1 Pesquisador visitante na University of Ljubljana (Eslovênia - 2017) com a supervisão do Prof. Dr. Ales Galic e na Università di Pisa (Itália - 2017) com a supervisão da Profa. Dra. Maria Angela Zumpano. Pós-doutorado Direito na Università degli Studi di Messina (Itália, 2015-2016) com a supervisão do Prof. Dr. Mario Trimarchi. Pós-doutorado em Direito Ambiental no CENoR da Faculdade de de Direito da Universidade de Coimbra (Portugal, 2014-2015) com a supervisão da Prof Catedrática Dra. Maria Alexandra Sousa Aragão. Pós-doutorado em Direito Constitucional junto ao Ius Gentium Conimbrigae/Centro de Direitos Humanos (IGC-CDH) da Faculdade de Direito da Universidade de Coimbra (Portugal, 2013-2014) com a supervisão do Prof. Catedrático Dr. Jónatas Eduardo Mendes Machado. Doutorado em Direito pela Universidade Gama Filho do Rio de Janeiro-RJ (área de concentração em Estado e Direito: internacionalização e regulação) (2006-2010) com a orientação do Prof. Dr. Guilherme Calmon Nogueira da Gama. Mestrado em Direito pela Faculdade de Direito Milton Campos de Belo Horizonte-MG (área de concentração em Direito Empresarial) (1998-2001) com a orientação do Prof. Dr. Alberto Deodato Maia Barreto Filho. Especialização lato sensu pela Universidade Presidente Antônio Carlos em Direito Público (2002) e em Direito Civil (2003). Possui graduação em Direito pela Universidade Presidente Antônio Carlos (1984). Atualmente é Professor da Graduação e do PPGD - Mestrado e Doutorado em Direito Proteção dos Direitos Fundamentais da Universidade de Itaúna - UIT (o8/2016) e das Faculdades Santo Agostinho - FASASETE (02/2018). email: deilton.ribeiro@terra.com.br 2 Possui graduação em Direito pela Universidade Estadual de Montes Claros(2004) e especialização em Direito Notarial e Registral pela Universidade Anhanguera - Uniderp(2017). Mestranda em Direito pela Universidade de Itaúna. Atualmente é Oficial Titular do Registro Civil das Pessoas Naturais. email: tatiannyvelosogomes@hotmail.com
\end{abstract}


and doctrine following the deductive-descriptive method, the results obtained were in the sense of highlighting any innovations brought by said law to the legal institutes of asylum and refuge, outlining their similarities and differences.

Keywords: Right of Asylum. Access to shelter. Migration Act. Dualism. Innovations.

\section{INTRODUÇÃO}

O objetivo do presente trabalho é a análise da Lei no 13.445 de 24 de maio de 2017 (Lei de Migração), regulamentada pelo Decreto no 9.199 de 20 de novembro de 2017 em especial nos dispositivos que tratam dos institutos do direito de asilo e de refúgio. A problematização é no sentido de averiguar se a normativa em questão trouxe alguma inovação aos institutos de proteção dos refugiados em questão. Para tanto, desenvolver-se-á estudos relativos à natureza jurídica de cada um deles com o fim de justificar o dualismo asilo/refúgio presente no ordenamento jurídico pátrio para a final apontar as semelhanças e diferenças situando-os no ordenamento jurídico pátrio (BRASIL, 2017).

Partindo de uma análise abrangente que abordará os mais relevantes instrumentos internacionais de proteção dos refugiados, serão estudados os vários debates que se produziram em torno da inclusão do asilo e refúgio nas diversas versões da Declaração Universal de Direitos Humanos de 1948, documento que consagra o respeito aos direitos inerentes à dignidade humana, consistente em resposta às atrocidades vivenciadas na Segunda Guerra Mundial (1939-1945) que gerou um contingente migratório a nível mundial.

Apontados os delineamentos do asilo e refúgio no Direito Internacional, partirse-á para a análise das normativas editadas pelo legislador brasileiro, tal como, a Lei no 9.474/97 que instituiu normas de acolhida para as pessoas que procuram refúgio no Brasil. Sequencialmente após um breve estudo das políticas migratórias implementadas pela Lei de Migração.

A escolha do tema justifica-se em razão da necessidade de explicitar o tratamento legal dispensado pelo Direito àqueles que, aqui, buscam serem acolhidos na medida em que os instrumentos adequados para abarcar e atender demandas, individuais e coletivas, de contingentes humanos marcados pela perseguição e desrespeito aos direitos que garantem o mínimo existencial que devem estar presentes na legislação pátria.

Além disso, a pontual diferenciação entre os institutos é relevante, na medida em, apesar da discricionariedade inerente ao ato, são necessários o cumprimento de alguns requisitos para o reconhecimento do status de refugiado ou asilado se aperfeiçoe e a coexistência dos dois sistemas de proteção gera, muitas das vezes, dificuldade de aplicação e dúvidas conceituais, além de dar margem à tomada de decisões viciadas em sua origem em razão de procedimento errôneo adotado, motivo pelo qual o delineamento de um e outro é necessário.

O tema foi explorado a partir de uma pesquisa bibliográfica com revisão da legislação e doutrina, o que permitiu o desenvolvimento de interpretações, reflexões e críticas acerca dos institutos estudados, viabilizando, desse modo, o debate crítico-epistemológico. A pesquisa documental permitiu o conhecimento da legislação, tanto o direito internacional dos refugiados quanto o nacional, incluindo constitucional e a legislação infraconstitucional.

Com o fim de delimitar o problema teórico foi utilizado o método descritivo-dedutivo, tendo como ponto de partida a concepção macroanalítica do estudo sobre os institutos jurídicos do asilo e refúgio, por meio da análise de documentos internacionais ratificados 
pelo Brasil, o que permite um pontual delineamento dos instrumentos protetivos em estudo na ordem jurídica nacional.

Os institutos de asilo e de refúgio consistem em sistemas de proteção de indivíduos que sofrem perseguições políticas, religiosas ou em razão da raça, nacionalidade ou pertencimento a determinado grupo social. Alguns Estados não reconhecem a existência de dualismo entre os institutos em questão, tratando-os da mesma forma, seguindo o mesmo procedimento para circunstâncias diversas, outros, como é o caso do Brasil reconhece essa dicotomia e estabelece regras diversas para a concessão e procedimento de uma e outra medida protetiva.

\section{ALGUMAS CONSIDERAÇÕES SOBRE OS TERMOS ASILO E REFÚGIO}

O tópico a ser desenvolvido objetiva traçar esclarecimentos acerca dos termos: asilo e refúgio, afim de justificar a utilização das nomenclaturas no decorrer do presente estudo. Partese de uma análise dos institutos em âmbito de direito internacional para, posteriormente, traçar os delineamentos normativos no sistema jurídico pátrio até a recente Lei de Migração - Lei no 13.445/2017 e seu Decreto regulamentador - Decreto no 9.199/17 de modo que se fazem necessárias algumas pontuações acerca dos termos (BRASIL, 2017).

Os institutos jurídicos têm como objetivo a proteção da pessoa humana nas hipóteses em que o Estado de origem não oferece a adequada garantia protetiva. A acolhida de estrangeiros perseguidos sempre foi amplamente difundida e praticada, daí a necessidade de positivá-la, tornando-a um instituto eficaz e efetivo na proteção das pessoas em âmbito internacional.

Essa positivação ocorreu modernamente, estabelecendo-se o direito de asilo em sentido amplo, sob o qual estão abrangidos o asilo diplomático e territorial e o refúgio, em razão disso, as expressões, em diversas legislações são utilizadas como sinônimos.

A Declaração Universal dos Direitos do Homem de 19483, aprovada pela Assembleia Geral da ONU, é o alicerce jurídico para as diversas modalidades de normativas protetivas. O documento traz o termo asilo para referir- se tanto ao refúgio quanto ao asilo. Na medida em que ambos os institutos visam à proteção do ser humano em face de perseguições, é possível afirma que são similares em sua essência e, dessa maneira, institutos assemelhados (ONU, 1948).

Asilo e refúgio possuem um caráter de complementaridade, sendo o instituto do asilo mais abrangente, podendo ser usado quando não há a possibilidade de aplicação do refúgio que é mais específico. A semelhança da natureza dos institutos pode ser comprovada pela leitura do $4^{\mathrm{o}}$ parágrafo ${ }^{4}$ preambular da Convenção de Genebra de $1951^{5}$, que, ao estabelecer as regras internacionais sobre o refúgio, menciona o direito de asilo, invocando, assim, este como base para aquele, ao mesmo tempo em que exorta os Estados a praticar a cooperação internacional (JUBILUT, 2007, p.36-37), (ONU, 1951).

3 A Declaração Universal dos Direitos Humanos, adotada e proclamada pela Assembleia Geral da ONU na Resolução 217-A (III) de 10 de dezembro de 1948, foi um acontecimento histórico de grande relevância. Ao afirmar, pela primeira vez em escala planetária, o papel dos direitos humanos na convivência coletiva, pode ser considerada um evento inaugural de uma nova concepção da vida internacional. Disponível em: https://declaracao1948.com.br/declaracao-universal/historia-da-declaracao-por-celso-lafer/ declaracao-universal-dos-direitos-humanos-1948. Acesso em: 10 jan. 2019.

4 Artigo 4º da Convenção de Genebra de 1951: Considerando que da concessão do direito de asilo podem resultar encargos excepcionalmente pesados para alguns países e que a solução satisfatória dos problemas cujo alcance e natureza internacionais a Organização das Nações Unidas reconheceu, não pode, portanto, ser obtida sem cooperação internacional. Disponível em: http:// www.planalto.gov.br/ccivil_03/decreto/1950-1969/D50215.htm. Acesso em: 02 jan. 2019.

5 Adotada a 12 de Agosto de 1949 pela Conferência Diplomática destinada a Elaborar as Convenções Internacionais para a Proteção das Vítimas da Guerra, que reuniu em Genebra de 21 de Abril a 12 de Agosto de 1949. Entrada em vigor na ordem internacional: 21 de Outubro de 1950. Disponível em: http://www.direitoshumanos.usp.br/index.php/Convenconvencao-de-genebra-iv.html. Acesso em: 10 jan. 2019. 
Embora o termo asilo seja frequentemente utilizado de forma abrangente para abarcar as duas medidas protetivas, alguns estudiosos dos institutos entendem que não há distinção entre asilo e refúgio, sendo, por eles, adotado sempre a expressão asilo. Tal posicionamento é o da maior parte dos Estados. Para os adeptos da unidade dos institutos, tem-se que os buscadores de asilo são todos os seres humanos que deixam seu país de origem e/ou de residência habitual e buscam proteção em outro Estado, e os refugiados são os que solicitam a proteção de outro Estado em função de um bem fundado temor de perseguição. A proteção concedida a todos seria a do asilo (JUBILIT, 2007, p. 36)

Oportuno ressaltar, porém, que o asilo é um instituto jurídico mais comum na América Latina, onde coexistem o sistema latinoamericano de asilo e o sistema das Nações Unidas de proteção aos refugiados, enquanto que nos demais Estados o asilo é utilizado apenas enquanto modo de proteção provisória. Embora tenham o mesmo objetivo final, importantes aspectos relativos à aplicabilidade da proteção e aos deveres do Estado acolhedor diferenciam os dois institutos. Todavia tais diferenças não se mostram muito claras para os estudiosos da temática, verificando-se, muitas das vezes, os termos sendo utilizados como expressões sinônimas, o que gera certa confusão no ordenamento jurídico.

Como um dos objetos do presente estudo é a análise do direito dos refugiados no ordenamento jurídico pátrio com foco nas normativas específicas, bem como na Lei no 13.445/2017, optou-se por desenvolver o estudo acerca das diferenças entre os institutos, já que o sistema jurídico brasileiro as consideram (BRASIL, 2017).

\subsection{Previsão do asilo e refúgio na Declaração Universal dos Direitos Humanos}

Os Estados contemporâneos, após vivenciar as atrocidades e horrores da Segunda Guerra Mundial, período compreendido entre os anos de 1939 - 1945 mobilizam-se para a reconstrução dos direitos humanos. Neste cenário, inicia a elaboração da Declaração Universal dos Direitos Humanos em 1948, trazendo uma concepção contemporânea de direitos humanos como paradigma e referencial ético a nortear o sistema internacional e integrar os direitos da pessoa humana. A segunda guerra significou a ruptura com os direitos humanos e o pósguerra a reconstrução.

Sobre o tema, Carolina Henriques Pereira pontua:

A Segunda Guerra Mundial legou à Europa e ao mundo um cenário de devastação material e humana sem precedentes na contemporaneidade. Os avanços a Leste e a Oeste das tropas alemãs conduziram a um afluxo de milhares de judeus e não-judeus nos territórios europeus. A fuga prosseguia à medida que os territórios onde se encontravam iam sendo sucessivamente invadido e ocupados pelo nazismo (PEREIRA, 2017, p. 36)

Momento histórico em que a comunidade internacional percebe que se fazia necessária a regulamentação internacional da questão, para que as atrocidades cometidas durante os conflitos da guerra não se repetissem.

Diante disso, em 1945 criou-se a ONU, organização intergovernamental, de caráter universal e representativa da comunidade internacional, para atuar, assegurar e garantir a manutenção da segurança e da paz internacionais, eivando esforços no desenvolvimento de relações amistosas e menos hostis entre os Estados, viabilizando, desse modo, a cooperação entre as comunidades, enfaticamente na defesa dos direitos humanos. Referida organização atua como um harmonizador, conciliador e mediador das ações internacionais. Em 1948 houve a edição da Declaração Universal dos Direitos 
Humanos. Marcava-se, com isso, o início de importante etapa do desenvolvimento dos direitos humanos, a sua internacionalização.

A Declaração Universal dos Direitos do Homem (1948) passou a simbolizar o início da internacionalização dos direitos humanos. Trata-se de um diploma contendo os princípios norteadores da comunidade internacional. A partir deste documento, os Estados soberanos passam a assegurar direitos essenciais, a ordem internacional reconhece e garante direitos inerentes à condição humana, havendo, por parte da comunidade internacional a assunção de respeito e garantia desses direitos.

Nas palavras de Fábio Konder Comparato o Direito Internacional dos Refugiados tem reflexos diretos da internacionalização dos direitos humanos, uma vez que:

\begin{abstract}
A internacionalização dos direitos humanos se materializa em uma pletora de tratados e convenções, transformando o indivíduo em sujeito do Direito Internacional. A formação de um espaço público internacional dos direitos humanos alimentado pelos meios de comunicação enfraqueceu o apelo político ao conceito de soberania para encobrir a prática de perseguições, massacres e torturas contra minorias étnicas e opositores políticos (COMPARATO, 2017, p. 57).
\end{abstract}

Iniciado o processo de internacionalização, passaram a ser elaborados tratados convenções cujo objeto é o aperfeiçoamento e proteção dos direitos humanos, por meio de normativas caracterizadas pela especificidade e especialização de conteúdo e sujeitos. A título de exemplo cita-se: a Convenção para a Prevenção e a Repressão do Crime de Genocídio (1948), a Convenção Europeia de Direitos Humanos (1950), a Convenção sobre a Eliminação de Todas as Formas de discriminação Racial (1965), os Pactos Internacionais de Direitos Humanos (1966), a Convenção Americana de Direitos Humanos (1969), a Convenção Relativa à Proteção do Patrimônio Mundial, Cultural e Natural (1972), a Carta Africana dos Direitos Humanos e dos Direitos dos Povos (1981). Nas convenções e tratados mencionados, verificase a previsão e proteção dos direitos dos refugiados, embora não tratem, especificamente, do assunto, o que demonstra a relevância dessas garantias para as comunidade contemporâneas.

Os institutos jurídicos em questão tem por objeto a proteção de pessoas que são perseguidas dentro de seus países de origem, sendo, pois, obrigadas a se deslocar para outro local .

Flávia Piovesan afirma que:

A proteção internacional dos refugiados se opera mediante uma estrutura de direitos individuais e responsabilidade estatal que deriva da mesma base filosófica que a proteção internacional dos direitos humanos. O Direito Internacional dos Direitos Humanos é a fonte dos princípios de proteção dos refugiados e ao mesmo tempo complementa tal proteção (PIOVESAN, 2018, p. 98).

Estabelece-se, assim, um axioma jurídico internacional de proteção da pessoa humana em casos de paz que é integrado pela previsão de direitos que protegem indivíduos em situações especiais, como é o caso dos refugiados, sendo congregadas ao sistema previsões específicas de proteção, formando um Direito Internacional dos Refugiados.

Sobre a temática, Liliana Lyra Jubilut preleciona que,

Tem-se que o Direito Internacional dos Refugiados é uma vertente do Direito Internacional dos Direitos Humanos, do que decorre aspectos positivos, já que em sendo um ramo do Direito Internacional dos Direitos Humanos, o Direito Internacional dos Refugiados conta tanto com todos os instrumentos legais daquele, bem como com seus mecanismos de implementação. Tal fato é extremamente positivo, pois fortalece a proteção ao refugiado, uma vez que, ao mesmo tempo em que se assegura 
o refúgio, livrando-o de violações de direitos relativos ao seu status civil, ele traz em si a necessidade de resguardar também os demais direitos humanos, para, com isso, aumentar o nível de proteção dado à pessoa humana. Além disso, verifica-se uma crescente preocupação com a temática dos direitos humanos, especialmente por meio da proliferação de organizações não-governamentais, que vêm colocando-a na agenda global, contribuindo para reflexões e cobranças quanto à sua efetivação, fato do qual se aproveita o Direito Internacional dos Refugiados (JUBILUT, 2007, p. 109).

O Direito Internacional dos Refugiados aplica-se aos migrantes do momento em que abandonam o seu país de origem até o momento de sua chegada no país de destino, propiciando o reconhecimento da condição de refúgio, o que permite a permanência legal e usufruto dos benefícios e direitos do país de destino.

No período da segunda guerra houve uma fuga de grande contingente de pessoas que prolongou no pós-guerra, o número de refugiados era crescente, todavia não se verifica a adequada proteção a essas pessoas. Diante da situação que se afigura, os Estados conferem relevância aos institutos asilo e refúgio em âmbito da Declaração Universal dos Direitos Humanos. De fato, trata-se de temática que merece a devida atenção e garantia, já que objetiva proteger aqueles que estão desprovidos de proteção em suas próprias nações.

A relevância dos institutos em estudo é evidente para aos Estados contemporâneos que além de incluir referidas garantias no texto da Declaração Universal dos Direitos Humanos, incluiu-os em pauta de discussão nas seis versões anteriores ao texto final da Declaração.

Segundo ainda Liliana Lyra Jubilut destaca -se :

\begin{abstract}
O direito de asilo apareceu na primeira versão do processo de elaboração da Declaração Universal dos Direitos do Homem - 1948 no artigo 34 cujo texto dispunha: Todo Estado deve ter direito de conceder asilo a refugiados políticos - nota-se que o direito não era do individuo e sim do Estado que estava restrito a refugiados políticos. Este texto foi mantido na segunda versão (...) já na terceira versão, o direito se tornou individual e a questão passou a ser a de se ele implicaria o direito de solicitar e gozar asilo, uma vez que esse foi concedido, ou no direito de ter asilo concedido. Mais uma vez os interesses os Estados, apresentados sob a questão da soberania, prevalecera (...), Na versão seguinte, a de Genebra, o direito de asilo foi consagrado no artigo 11 e não somente passou a ser o direito de ter asilo concedido com sofreu limitações em relação a quem poderia gozar. Contudo, na última versão antes da adoção do texto final - a de dezembro de 1948 o direito de asilo perdeu força ao ter a sua concessão substituída por seu gozo. : 1- Artigo 14: Todos têm direito de buscar e gozar de asilo em função de perseguição, em outros Estados. 2. Persecuções processuais decorrentes de crimes não políticos e de atos contrários aos propósitos das Nações Unidas não constituem perseguição. Apesar de não ser a forma ideal de proteção, pois não obriga a concessão de asilo, denota uma evolução do instituto, já que existe, a partir desse diploma legal, uma base internacional positivada para o direito de asilo em geral (JUBILUT, 2007, p. 112).
\end{abstract}

Muito curiosa a utilização do termo asilo nas várias versões da Declaração Universal dos Direitos Humanos, por qual razão referido termo é utilizado e não se menciona o instituto do refúgio? Tal se dá não em razão de priorizar um em detrimento de outro. $\mathrm{O}$ motivo encontra-se, como visto, na origem do instituto.

Também se pontua, mais uma vez, que vários Estados não apresentam diferenciação entre os termos, utilizando-os indiscriminadamente como sinônimos. Importante destacar que a utilização do termo asilo não significa dizer que somente referido instituto protetivo foi previsto pela Declaração, na verdade, o que se pretende com referida previsão é o disciplinamento de ambos. 
Denota-se que a edição da Declaração Universal de Direitos Humanos, como base normativa que é, ensejou a elaboração de outras normas internacionais de proteção, o que confere um delineamento cada vez mais elaborado dos institutos em estudo.

\section{PRINCIPAIS DIFERENÇAS ENTRE O DIREITO DE ASILO E DE REFÚGIO}

Tendo em vista o objetivo do presente estudo, pretende-se, neste tópico, traçar as diferenças entre asilo e refúgio, ambos os institutos se fundamentam na solidariedade e cooperação internacional e estão relacionados à proteção de indivíduos que sofrem perseguições políticas ou de qualquer outra natureza e que deixaram de ter acolhida no território de origem.

O sistema jurídico pátrio traz textos normativos que disciplinam, especificamente, tais medidas protetivas, verifica-se que os institutos são invocados para situações discriminadas e específicas, tanto que nas normas jurídicas regulamentadoras, há capitulo próprio para tratar o refúgio separadamente daquele que trata o asilo, é o que ocorre, por exemplo, na Lei no 13.445/2017. Há lei que disciplina exclusivamente o refúgio e normativa exclusiva para o asilo, havendo um claro dualismo no que tange a tais medidas protetivas.

A coexistência dos dois sistemas de proteção aos indivíduos faz com que exista dificuldade de aplicação e incertezas conceituais acerca de um e outro termo, por isso optouse por traçar de forma pontual as diferenças existente entre ambos.

\subsection{Algumas considerações adicionais sobre o instituto do asilo}

Registros revelam que o asilo tem sua origem na antiguidade clássica, especificamente, na civilização grega, época em que era, recorrentemente utilizado, originando daí a sua denominação asylon que significa não- expulsão (ANDRADE, 2001, p. 104). Neste período os templos religiosos eram designados como locais de acolhida dos perseguidos, o benefício era proporcionado aos escravos fugitivos, soldados vencidos e criminosos comuns. A literatura aponta que na Grécia antiga, o asilo tinha enorme relevância e foi bastante utilizado em templos, bosques sagrados, impondo-se, naquela época, que o perseguido carregasse consigo o busto portátil de divindades (ANDRADE, 2001, p. 101-102). Nota-se que nesta civilização, o asilo restringia-se a aspectos religiosos.

O caráter jurídico do asilo é verificado no Império Romano, período em que não mais se restringe ao cunho religioso. Apesar disso, durante a Idade Média, esse instituto retrocedeu, limitando-se a igrejas e cemitérios. Apenas com a Reforma Protestante o asilo passa a ser novamente defendido como modo de proteção da liberdade individual dos seres humanos (JUBILUT, 2007, p. 37) .

Em 1789, com a Revolução Francesa, o asilo sofre uma relevante mudança consistente em restringir a concessão do beneficio jurídico aos criminosos políticos, a partir de então, não mais se usufrui do asilo os criminosos comuns. Nas palavras de Haroldo Teixeira Valladão (1986, p. 237), o asilo é a "admissão, por um Estado, em seu território, ou, fora dele, no local da sua representação diplomática ou da residência do chefe desta última ou em seus navios ou aeronaves militares, de estrangeiro refugiado, perseguido em outro Estado por motivo político".

O conceito revela a existência de duas espécies de asilo, o diplomático e o territorial, classificação que considera o lugar onde se encontra o refugiado. O primeiro é concedido 
em extensões do território do Estado de acolhida, possui caráter provisório, já que o serviço diplomático ou militar que admitiu o perseguido deve providenciar o encaminhamento do asilado para o território do país solicitado, ou na hipótese de não concessão de asilo diplomático, o perseguido deve ser encaminhado para o solo de um terceiro país que o aceite como asilado político.

$\mathrm{Na}$ hipótese do asilo territorial, o perseguido encontra-se fisicamente no âmbito do espaço territorial de soberania do Estado solicitado, caso em que o asilado está sob jurisdição exclusiva deste Estado, cabendo à ele fiscalizar eventuais infrações cometidas pelo perseguido e de providenciar a documentação para o asilado, assegurar a proteção, impondo limites à saída compulsória do país.

Outro aspecto a ser destacado é o fato de ser um benefício concedido à perseguidos políticos, ou seja, o que motiva a concessão é a perseguição por razões políticas. Ademais, em que pese ser um instrumento jurídico de proteção à pessoa humana, o asilo é direito do Estado, em outras palavras nenhum Estado obriga-se a aceitar qualquer pessoa em seu território, daí o caráter discricionário da decisão estatal que deve basear na solidariedade e cooperação internacional. A principal fonte legal desse benefício é o respeito aos direitos humanos.

O asilo político revela-se instituto que integra os direitos dos refugiados, principalmente, ante a possibilidade de sua concessão em situação extraterritorial, como é o caso do asilo diplomático. Todavia, por outro lado, limita a proteção ao concedê-la àqueles que sofrem perseguições exclusivamente políticas. Além disso, o que se observa nos tratados e convenções é ausência de políticas de integração local a serrem implementadas por parte dos Estados de acolhida.

\subsection{Algumas considerações adicionais sobre o direito de refúgio}

Ao contrário do asilo, o refúgio é um beneficio de solidariedade internacional mais recente a ser usufruído não só pelos que sofrem perseguições políticas, mas por todas as pessoas que não encontram em seu país de origem o mínimo existencial para satisfazer as necessidades básicas de uma vida digna.

A já mencionada Convenção de 1951 e o Protocolo de $1967^{6}$, documento conhecido como o Estatuto dos Refugiados definiu os refugiados como aqueles que saem de seus países de origem por motivos de perseguições de raça, religião, nacionalidade, liberdade de expressão política ou questões sociais que não possam ou não queiram voltar de onde vieram (ONU, 1951). A motivação para a concessão de refúgio é bem mais abrangente que aquela para a admissão de asilo.

Sobre as origens do refúgio, conforme ensina Liliana Lyra Jubilut:

O instituto do refúgio surge apenas no início do século $X X$, sob a égide da Liga das Nações em face de um contingente elevado de pessoas perseguidas na União das Repúblicas Socialistas Soviéticas, para as quais seria impossível uma qualificação individual por meio do instituto do asilo, dado que nenhum Estado estaria disposto a, discricionariamente, acolher milhares de pessoas, sendo necessária uma qualificação coletiva que lhes assegurasse a proteção internacional (JUBILUT, 2007, p. 43)

6 Protocolo de 67 teve como base um projeto de protocolo elaborado como anexo dos anais de um colóquio realizado em 1965 em Belágio, Itália, denominado de "Convenção de 51 - um colóquio sobre os aspectos legais dos problemas dos refugiados". O texto do Protocolo de 67 foi aprovado pela Resolução 2198 (XXI) em reunião plenária da Assembléia Geral da ONU de 16 de dezembro de 1966 e passou a vigorar em 4 de outubro de 1967. A aprovação foi por 91 votos a favor, zero contra e 15 abstenções, de acordo com a biblioteca da ONU em Genebra. O texto encontra-se disponível em: http://www.planalto.gov.br/ccivil_o3/decreto/1970-1979/ D70946.htm. Acesso em: 03 jan. 2019. 
No acervo que criou Liga das Nações não há previsão expressa acerca de obrigações de acolhimento aos refugiados, tal organização no afã de alcançar soluções para a questão criou diversos organismos para assegurar a proteção aos refugiados.

Contudo, durante muito tempo, a proteção viabilizada por estes organismos se restringia à concessão de uma nacionalidade ou etnia específica, em outras palavras não um programa de integração para as pessoas refugiadas.

Com o intuito de padronizar o tratamento aos refugiados, em 1938, a Liga das Nações instaurou o Alto Comissariado da Liga das Nações para Refugiados ${ }^{7}$ que estabeleceu critérios para o reconhecimento do status refugiado, passando a fundamentar a qualificação em aspectos individuais em coexistência com os já previstos aspectos coletivos, presentes nacionalidade e etnia como principais critérios.

As atrocidades produzidas pelas duas Guerras Mundiais produziu um enorme contigente de refugiados, cenário que não pode ser contornado pelo Alto Comissariado da Liga das Nações para Refugiados, ante a ausência de estrutura para atender a todos os migrantes forçados por estes conflitos. "Diante da incapacidade e ineficácia deste órgão, bem como o declínio da Liga das Nações, os Estados Unidos criaram, em 1938, o Comitê Intergovernamental para os Refugiados, que atuava paralelamente ao Alto Comissariado da Liga das Nações" (ANONNI; VALDES, 2013, p. 75)

\footnotetext{
Em 1946, o Alto Comissariado foi extinto e o Comitê Intergovernamental assumiu as suas funções. Todavia, referido Comitê funcionou somente até 1947, época em que a proteção aos refugiados passou, provisoriamente, para a responsabilidade da Comissão Preparatória da Organização Internacional para Refugiados, órgão ligado à ONU que, posteriormente, em 1950, foi sucedido pelo Alto Comissariado das Nações Unidas para Refugiados (ACNUR). Desde esse período, o ACNUR, que atua no âmbito da ONU tem o seu regulamento revisto e reformulado a cada cinco anos e permanece responsável pelos refugiados (JUBILUT, 2007, p. 78-80).
}

A criação do Alto Comissariado da Liga das Nações para Refugiados - ACNUR - marca a edição dos mais relevantes instrumentos internacionais jurídicos para delinear o instituto jurídico do refúgio. De todo o acervo documental, cita-se a já mencionada Convenção Relativa ao Estatuto dos Refugiados - Convenção de 51 e o Protocolo Relativo ao Estatuto dos Refugiados Protocolo de 67.

Diferentemente do asilo, o refúgio dispõe de vasta regulamentação, certamente, tal se deu em decorrência dos contingentes migratórios produzidos pelo pós-guerra. O instituto possui o seu procedimento regulamentado, as hipóteses de concessão prevista e especificadas por normativas que tratam exclusivamente do assunto, fato que o qualifica como sendo um ato vinculado, contrariamente ao asilo que é, eminentemente, discricionário.

Em que pese a concessão do refúgio ser considerado um ato vinculado, há que se fazer algumas ponderações acerca dos termos legais contidos na norma. E, aqui, cita-se o teor do artigo $1^{\circ}$ da Convenção de 1951 que estipula uma definição para a situação de refugiado, conferindo a proteção a qualquer pessoa que, em virtude de fundado medo de sofrer perseguição por motivos de raça, religião, nacionalidade, participação em determinado grupo social ou convicção política, se encontra fora do país do qual é nacional e esta impossibilitada ou, em virtude desse fundado medo, não deseja se entregar à proteção desse país (ONU, 1951).

Pois bem, verifica-se, no texto da Convenção de 1951, conceitos extremamente abertos e de difícil delimitação, como, por exemplo: fundado medo de sofrer perseguição ou convicção

7 O Alto Comissariado das Nações Unidas para os Refugiados, com a sigla ACNUR em português e UNHCR em inglês, é um órgão das Nações Unidas. Criado pela Resolução n.ํㅜ 428 da Assembleia das Nações Unidas, tem como missão dar apoio e proteção a refugiados de todo o mundo. Sua sede é em Genebra, Suíça. Disponível em: https://www.acnur.org/portugues/. Acesso em: 10 jan. 2018. 
política - trata-se de conceituação com uma carga considerável de subjetivismo, o que acaba por conferir um elevado grau de discricionariedade quando da valoração, conferindo-lhe fortes traços de discricionariedade.

Referida conceituação além de evidenciar a discricionariedade inerente ao ato, revela ser o refúgio, benefício bem mais amplo que o asilo que é concedido somente na hipótese de perseguição por razões políticas, outra aspecto peculiar consiste no fato de que este benefício, diferente do asilo, não exige que a perseguição tenha sido concretizada, ou seja, fundado temor de que algo aconteça já é considerado suficiente para a admissão da medida protetiva.

Outro aspecto a ser pontuado é a exigência, na hipótese do refúgio, da extraterritorialidade, em outras palavras, exige que o perseguido esteja fisicamente fora do seu país, exigência não prevista para a concessão do asilo, já que é possível a forma de asilo diplomático, como visto.

Há que se ressaltar uma pontual diferença entre os institutos jurídicos que são as obrigações assumidas pelo Estado solicitante ao reconhecer o status de refugiado, fato que não ocorre quando da concessão do asilo ao asilado. O Instituto do asilo, trata-se de benefício bem menos dispendioso para o Estado concedente, já que este não se obriga, em razão de tratados internacionais, assim como ocorre no refúgio, a implementar políticas de integração para os acolhidos.

A coexistência dos dois sistemas de proteção do indivíduo torna imperiosa a pontuação da regulamentação e caracteres que os individualiza, tal é essencial para o entendimento da positivação dos institutos jurídicos em âmbito nacional. O Direito Brasileiro traz o disciplinamento de ambos, por meio de leis, doutrina e posicionamento dos tribunais superiores. A regulamentação internacional existe, como se demonstrou, todavia, os delineamentos do asilo e refúgio submetem-se à soberania dos Estados que possuem uma considerável medida de liberdade para o disciplinamento de ambos.

A seguir desenvolver-se-á tópico dedicado ao estudo da positivação dos institutos em âmbito nacional, trazendo algumas considerações sobre o tema no âmbito da nova Lei de Migração.

\section{O DIREITO DE ASILO E DE REFÚGIO NO CONTEXTO DA NOVA LEI DE MIGRAÇÃO BRASILEIRA}

O Brasil destaca-se no contexto regional, demonstrando comprometido com os sistemas normativos de proteção dos refugiados, tanto que foi o primeiro país sul americano a ratificar a Convenção de 1951 e o Protocolo de 1967, além disso integra o Conselho Executivo do Alto Comissariado das Nações Unidas para Refugiados (ACNUR) desde 1958.

O Estado brasileiro começou a se comprometer com as questões de refúgio mais profundamente no ano de 1977, quando realizou um acordo com o ACNUR para o estabelecimento de um escritório ad hoc na cidade do Rio de Janeiro. A necessidade de manter uma repartição da agência no Brasil era iminente, dada a interrupção da democracia na América Latina, o que gerou uma onda de movimentos opositores aos regimes militares e, consequentemente, refugiados (JUBILUT, 2007).

Com a promulgação da Constituição Federal de 1988 verificou-se um crescente interesse pela proteção dos refugiados e pelos direitos humanos. O texto constitucional traz em seu bojo a proteção às relações internacionais com amparo nos princípios previsto no artigo $4^{\mathbf{0}^{8}}$, dentre os quais se destaca: a prevalência dos direitos humanos, a cooperação entre 8 Artigo 4º: A República Federativa do Brasil rege-se em suas relações internacionais pelos seguintes princípios: I - independência 
os povos para o progresso da humanidade e a concessão do asilo político, garantindo direitos fundamentais e segurança a quem está submetido a perseguições políticas, religiosas, étnicas ou as decorrentes da nacionalidade, cultura e opinião política (BRASIL, 1988).

Assim, Deilton Ribeiro Brasil entende que,

O texto do preâmbulo revela que o Estado Democrático brasileiro instituído está destinado a assegurar o exercício dos direitos sociais e individuais e, considerá-los, como valores supremos de uma sociedade fraterna, pluralista e sem preconceitos, assim como a liberdade, a segurança, o bem-estar, o desenvolvimento, a igualdade e a justiça, devendo ser fundada na harmonia social e comprometida com a solução pacífica das controvérsias, tanto na ordem interna como, também, na ordem internacional (BRASIL, 2018, p. 760 ).

Neste contexto, em consonância com o texto constitucional, "todos são iguais perante a lei, sem distinção de qualquer natureza, garantindo-se aos brasileiros e aos estrangeiros residentes no País a inviolabilidade do direito à vida, à liberdade, à igualdade, à segurança e à propriedade" 9 . De modo que aqueles que ostentarem o status de refugiado gozará dos direitos constitucionais pátrios, além daqueles estabelecidos na Convenção de 1951 e seu Protocolo Adicional de 1967.

Em 1997, foi aprovada e promulgada a Lei no $9 \cdot 474 / 97^{10}$ integrando o ordenamento com o Estatuto Jurídico dos Refugiados e consagrando-se como um marco legal de proteção aos refugiados no Brasil. Além de oferecer um ambiente de proteção jurídico favorável àqueles que buscam acolhida (BRASIL, 1997).

Embora as legislações internas de outros países sigam o protocolo de designar um órgão responsável pela proteção dos refugiados, bem como procedimentos para a admissão do pedido de acolhida, o Brasil, com a Lei no 9.474/97 foi além das políticas migratórias, até então, implementadas, passando a disciplinar tantos os deslocamentos forçados, procedimento para requerer a condição de refugiado, quanto os direitos e obrigações dos refugiados (BRASIL, 1997).

No que se refere ao asilo, em âmbito nacional, o que se verifica é a ratificação pelo Brasil de duas convenções internacionais que tratam da temática. A Convenção Internacional sobre Asilo Diplomático"1 ${ }^{11}$, promulgada pelo Decreto no 42.628 de 1.957 e a Convenção Internacional sobre Asilo Territorial ${ }^{12}$ promulgada pelo Decreto nº 55.929 de 1965 . Tais convenções consistem no referencial para a regulamentação do instituto do asilo.

Neste ponto, vale destacar que além das normativas vigentes no sistema jurídico brasileiro, os Tribunais Superiores pátrios vêm se posicionando acerca dos direitos cabíveis

nacional; II - prevalência dos direitos humanos; III - autodeterminação dos povos; IV - não-intervenção; V - igualdade entre os Estados; VI - defesa da paz; VII - solução pacífica dos conflitos; VIII - repúdio ao terrorismo e ao racismo; IX - cooperação entre os povos para o progresso da humanidade; X - concessão de asilo político. Parágrafo único. A República Federativa do Brasil buscará a integração econômica, política, social e cultural dos povos da América Latina, visando à formação de uma comunidade latinoamericana de nações. Disponível em: http://www.planalto.gov.br/ccivil_o3/Constituicao/Constituicao.htm. Acesso em: 10 jan. 2019. 9 Artigo $5^{\circ}$ Todos são iguais perante a lei, sem distinção de qualquer natureza, garantindo-se aos brasileiros e aos estrangeiros residentes no País a inviolabilidade do direito à vida, à liberdade, à igualdade, à segurança eà propriedade, nos termos seguintes (...). Disponível em: http://www.planalto.gov.br/ccivil_03/Constituicao/Constituicao.htm. Acesso em: 10 jan. 2019.

10 Lei no 9.474 de 22 de julho de 1997, define mecanismos para a implementação do Estatuto dos Refugiados de 1951, e determina outras providências. Disponível em: http://www.planalto.gov.br/ccivil_03/leis/l9474.htm. Acesso em: 10 jan. 2019.

11 O Congresso Nacional aprovou pelo Decreto Legislativo no 13, de 11 de junho de 1957, a Convenção Sobre Asilo Diplomático, assinada em Caracas, a 28 de março de 1954; foi ratificada pelo Brasil pela Carta de 25 de junho de 1957 e depositada em 17 de setembro de 1957 junto a União Pan-americana, em Washington o Instrumento brasileiro de ratificação da referida Convenção (http://www. planalto.gov.br/ccivil_03/decreto/1950-1969/D42628.htm). Acesso em: o3 jan. 2019.

12 O Congresso Nacional aprovou pelo Decreto Legislativo no 34 de 1964 a Convenção sobre Asilo Territorial assinada em Caracas, a 28 de março de 1954 por ocasião da $10^{a}$ - Conferência Interamericana. E havendo sido depositado o respectivo instrumento de ratificação junto à União Pan-americana, em 14 de janeiro de 1965. Disponível em: http://www.planalto.gov.br/ccivil_03/decreto/1950-1969/ D55929.htm). Acesso em: 03 jan. 2019. 
aos refugiados. É o que se verifica por meio de julgado proferido pelo Superior Tribunal de Justiça, a seguir transcrito:

DIREITO INTERNACIONAL PÚBLICO. DIREITO COMPARADO. REFÚGIO POR PERSEGUIÇÃO RELIGIOSA. CONFLITO ISRAEL-PALESTINA. CONDIÇÕES. IMIGRAÇÃO DISFARÇADA. CONARE. REQUERIMENTO INDEFERIDO. MÉRITO DO ATO ADMISTRATIVO. REVISÃO. IMPOSSIBILIDADE. POLÍTICAS PÚBLICAS DE MIGRAÇÃO E RELAÇÕES EXTERIORES.

\section{$[\ldots]$}

2. O refúgio é reconhecido nas hipóteses em que a pessoa é obrigada a abandonar seu país por algum dos motivos elencados na Convenção Relativa ao Estatuto dos Refugiados de 1957 e cessa no momento em que aquelas circunstâncias deixam de existir. Exegese dos artigos ıº, III, e 38, V, da Lei no 9.474/97. 3. A concessão de refúgio, independentemente de ser considerado ato político ou ato administrativo, não é infenso a controle jurisdicional, sob o prisma da legalidade. 4. Em regra, o Poder Judiciário deve limitar-se a analisar os vícios de legalidade do procedimento da concessão do refúgio, sem reapreciar os critérios de conveniência e oportunidade. Precedentes do STJ. 5. Em casos que envolvem políticas públicas de migração e relações exteriores, mostra-se inadequado ao Judiciário, tirante situações excepcionais, adentrar as razões que motivam o ato de admissão de estrangeiros no território nacional, mormente quando o Estado deu ensejo à ampla defesa, ao contraditório e ao devido processo legal a estrangeiro cujo pedido foi regularmente apreciado por órgão formado por representantes do Departamento de Polícia Federal; do Alto Comissariado das Nações Unidas para Refugiados (ACNUR) e dos Ministérios da Justiça, das Relações Exteriores, do Trabalho, da Saúde, da Educação e do Desporto, nos termos do art. 14 da Lei 9.474/1997. Precedentes do STJ e do STF. 6. A tendência mundial é no sentido da restrição do papel do Poder Judiciário no que tange à análise das condições para concessão de asilo. Precedentes do Direito Comparado. 7. No Direito Internacional Público, o instituto jurídico do refúgio constitui exceção ao exercício ordinário do controle territorial das nações, uma das mais importantes prerrogativas de um Estado soberano. Cuida de concessão ad cautelam e precária de parcela da soberania nacional, pois o Estado-parte cede temporariamente seu território para ocupação por não súdito, sem juízo de conveniência ou oportunidade no momento da entrada, pois se motiva em situação delicada, em que urgem medidas de proteção imediatas e acordadas no plano supranacional. (...). (REsp 1174235/PR, Rel. Ministro HERMAN BENJAMIN, SEGUNDA TURMA, julgado em 04/11/2010, DJe 28/02/2012).

O julgado deixa clara a posição do judiciário no que se refere ao caráter discricionário do ato que concede qualquer das medidas protetivas para os perseguidos, tanto para o asilo quanto para o refúgio. No que toca ao direito de asilo nunca houve dúvida acerca da discricionariedade, a controvérsia surge em âmbito de refúgio, tendo em vista a regulamentação legal detalhada do instituto, o que, muita das vezes, conduz o ordenamento a entender tratar-se de ato totalmente vinculado. Todavia o Superior Tribunal de Justiça, em uma postura respeitosa a evitar o conflito entre as instituições, deixa a cargo, exclusivo, do Poder Executivo as decisões de concessão ou não do refúgio.

O Brasil mantendo a postura pioneira no que se refere à proteção dos refugiados, substitui o Estatuto do Estrangeiro (Lei no $6.815 / 80^{13}$ ) criado no regime militar pela nova Lei de Migração (Lei no 13.445/17) com o intuito de conferir maior amparo aos estrangeiros e refugiados. O texto legal retira a definição segundo a qual o estrangeiro tem que ser visto como uma ameaça à soberania nacional.

13 Lei no 6.815 de 19 de agosto de 1980 que define a situação jurídica do estrangeiro no Brasil e cria o Conselho Nacional de Imigração. Disponível em: http://www.planalto.gov.br/ccivil_03/LEIS/L6815.htm. Acesso em: 10 jan. 2019. 
Os artigos $3^{0_{14}} \mathrm{e} 4^{0_{15}}$ trazem os princípios e garantias que regem a condução da tratativas entre nacionais e estrangeiros, determinando que sejam norteadas pela universalidade, indivisibilidade, interdependência dos direitos humanos, acesso igualitário e livre do migrante a serviços, programas e benefícios sociais, bens públicos, educação, assistência jurídica integral pública, trabalho, moradia, serviço bancário e seguridade social e acolhida humanitária.

Desse modo, para Deilton Ribeiro Brasil a legislação brasileira demonstra preocupação em adequar-se às exigências internacionais, garantindo, cada vez mais, a mobilidade e liberdade das pessoas e protegendo os direitos dos imigrantes no país.

Em todas essas situações, os Estados, inevitavelmente, devem cumprir os compromissos internacionais assumidos convencionalmente ou de forma não-convencional, respeitando o jus cogens (conjunto de normas jurídicas imperiosas e inderrogáveis, as quais vinculam a todos os sujeitos do direito internacional independentemente de sua vontade), procedendo às reformulações legislativas internas. O Estado brasileiro segue essa linha de pensamento, com promulgação da Lei no 13.445, de 24 de maio de 2017 que foi regulamentada pelo Decreto no 9.199, de 20 de novembro de 2017 (BRASIL, 2018, p. 761.)

Ao instituto jurídico do asilo não há acréscimos relevantes com o advento da Lei no $13.445 / 17$. O texto normativo limita-se a proclamar que as "condições para concessão e manutenção de asilo"16 serão dispostas em regulamento próprio. O Decreto no 9.199/17 regulamentador da nova Lei de Migração dedica alguns artigos ao disciplinamento do asilo,

14 Artigo $3^{-0}$ A política migratória brasileira rege-se pelos seguintes princípios e diretrizes: I - universalidade, indivisibilidade e interdependência dos direitos humanos; II - repúdio e prevenção à xenofobia, ao racismo e a quaisquer formas de discriminação; III - não criminalização da migração; IV - não discriminação em razão dos critérios ou dos procedimentos pelos quais a pessoa foi admitida em território nacional; V - promoção de entrada regular e de regularização documental; VI - acolhida humanitária; VII - desenvolvimento econômico, turístico, social, cultural, esportivo, científico e tecnológico do Brasil; VIII - garantia do direito à reunião familiar; IX - igualdade de tratamento e de oportunidade ao migrante e a seus familiares; X - inclusão social, laboral e produtiva do migrante por meio de políticas públicas;XI - acesso igualitário e livre do migrante a serviços, programas e benefícios sociais, bens públicos, educação, assistência jurídica integral pública, trabalho, moradia, serviço bancário e seguridade social; XII promoção e difusão de direitos, liberdades, garantias e obrigações do migrante; XIII - diálogo social na formulação, na execução e na avaliação de políticas migratórias e promoção da participação cidadã do migrante; XIV - fortalecimento da integração econômica, política, social e cultural dos povos da América Latina, mediante constituição de espaços de cidadania e de livre circulação de pessoas; XV - cooperação internacional com Estados de origem, de trânsito e de destino de movimentos migratórios, a fim de garantir efetiva proteção aos direitos humanos do migrante; XVI - integração e desenvolvimento das regiões de fronteira e articulação de políticas públicas regionais capazes de garantir efetividade aos direitos do residente fronteiriço; XVII - proteção integral e atenção ao superior interesse da criança e do adolescente migrante; XVIII - observância ao disposto em tratado; XIX - proteção ao brasileiro no exterior; XX - migração e desenvolvimento humano no local de origem, como direitos inalienáveis de todas as pessoas; XXI - promoção do reconhecimento acadêmico e do exercício profissional no Brasil, nos termos da lei; e XXII - repúdio a práticas de expulsão ou de deportação coletivas. Disponível em: http://www.planalto.gov.br/ccivil_o3/_Ato2015-2018/2017/Lei/L13445.htm. Acesso em: 10 jan. 2019 .

15 Artigo $4^{\circ}$ Ao migrante é garantida no território nacional, em condição de igualdade com os nacionais, a inviolabilidade do direito à vida, à liberdade, à igualdade, à segurança e à propriedade, bem como são assegurados: I - direitos e liberdades civis, sociais, culturais e econômicos; II - direito à liberdade de circulação em território nacional; III - direito à reunião familiar do migrante com seu cônjuge ou companheiro e seus filhos, familiares e dependentes; IV - medidas de proteção a vítimas e testemunhas de crimes e de violações de direitos; V - direito de transferir recursos decorrentes de sua renda e economias pessoais a outro país, observada a legislação aplicável; VI - direito de reunião para fins pacíficos; VII - direito de associação, inclusive sindical, para fins lícitos; VIII - acesso a serviços públicos de saúde e de assistência social e à previdência social, nos termos da lei, sem discriminação em razão da nacionalidade e da condição migratória; IX - amplo acesso à justiça e à assistência jurídica integral gratuita aos que comprovarem insuficiência de recursos; X - direito à educação pública, vedada a discriminação em razão da nacionalidade e da condição migratória; XI - garantia de cumprimento de obrigações legais e contratuais trabalhistas e de aplicação das normas de proteção ao trabalhador, sem discriminação em razão da nacionalidade e da condição migratória; XII - isenção das taxas de que trata esta Lei, mediante declaração de hipossuficiência econômica, na forma de regulamento; XIII - direito de acesso à informação e garantia de confidencialidade quanto aos dados pessoais do migrante, nos termos da; $\mathrm{V}$ - direito a abertura de conta bancária; XV - direito de sair, de permanecer e de reingressar em território nacional, mesmo enquanto pendente pedido de autorização de residência, de prorrogação de estada ou de transformação de visto em autorização de residência; e XVI - direito do imigrante de ser informado sobre as garantias que lhe são asseguradas para fins de regularização migratória. (...). Disponível em: http://www. planalto.gov.br/ccivil_03/_Ato2015-2018/2017/Lei/L13445.htm. Acesso em: 10 jan. 2019.

16 Artigo 27. O asilo político, que constitui ato discricionário do Estado, poderá ser diplomático ou territorial e será outorgado como instrumento de proteção à pessoa. Parágrafo único. Regulamento disporá sobre as condições para a concessão e a manutenção de asilo. Disponível em: http://www.planalto.gov.br/ccivil_03/_Ato2015-2018/2017/Lei/L13445.htm. Acesso em: 10 jan. 2019. 
não se vislumbrando, todavia, nenhuma inovação em relação à Convenção Internacional sobre Asilo Diplomático e Convenção Internacional sobre Asilo Territorial, ambas promulgadas pelo Brasil, conforme já mencionado.

Em que pese a ausência de relevantes inovações, há que se ressaltar as garantias

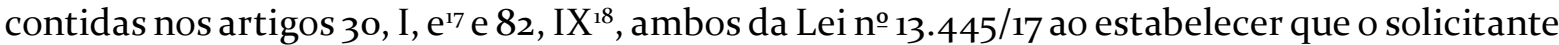
de asilo fará jus à autorização provisória de residência até a obtenção ou não da concessão e ao vedar a extradição do asilado, mandamento legal não encontrado nas citadas convenções.

Quanto ao instituto do refúgio, a Lei nº 13.445/17 determina que "a Política de Migrações, Refúgio e Apatridia será articulada conforme regulamento."199 $\mathrm{O}$ ato regulamentador da Lei - o Decreto no 9.199/17 dedica dois artigos ao tema "refúgio", os artigos $122^{20}$ e $181^{21}$, o primeiro para priorizar as solicitações de refúgio para as hipótese em que haja contra o refugiado medida de retirada compulsória e o artigo 181 a proibir a repatriação, deportação ou expulsão enquanto o processo de reconhecimento de sua condição estiver pendente.

A Lei no 13.445/17, bem como o seu Decreto regulamentador no 9.199/17 trouxe poucas inovações a integrar os institutos jurídicos em estudo. A existência da Lei no 9.474/97 e das convenções internacionais sobre asilo diplomático e territorial que foram ratificadas pelo Brasil, disciplinam os institutos de modo a alcançar uma adequada regulamentação das medidas protetivas.

Todavia, em que pese a suficiência de tais regulamentações, não se pode negar o critério pontual dos dispositivos contidos na nova Lei de Migração ao estabelecer as citadas garantias de residência provisória e não extradição não previstas nos regulamentos, até então, presentes no ordenamento pátrio, o que vem ratificar a política migratória adotada pelo Brasil no sentido de conferir acolhida àqueles que necessitam.

\section{CONSIDERAÇÕES FINAIS}

A política migratória nacional destaca-se no cenário da América do Sul por, sempre, estar à frente dos demais Estados quando o assunto é proteção de refugiados, tanto é assim que foi o primeiro país latinoamericano a ratificar a Convenção de 1951 e o Protocolo de 1967, comprometendo-se, desse modo, a respeitar e implementar o direito das pessoas que buscam acolhida. Com a edição da nova Lei de Migração não foi diferente, já que um dos princípios a nortear as tratativas dispensadas pelos nacionais aos estrangeiros é a acolhida humanitária artigo $3^{\circ}$ inciso IV da Lei no ${ }^{13.445 / 17 . ~}$

Como resultado final foi constatado que, em âmbito nacional, há o dualismo entre asilo e refúgio, característica dos países latinoamericanos, havendo, pois, regulamentação e

17 Artigo 3o, I, e: A residência poderá ser autorizada, mediante registro, ao imigrante, ao residente fronteiriço ou ao visitante que se enquadre em uma das seguintes hipóteses: I - a residência tenha como finalidade: e) seja beneficiária de refúgio, de asilo ou de proteção ao apátrida (...). Disponível em: http://www.planalto.gov.br/ccivil_03/_Ato2015-2018/2017/Lei/L13445.htm. Acesso em: 10 jan. 2019.

18 Artigo 82. Não se concederá a extradição quando: IX - o extraditando for beneficiário de refúgio, nos termos da Lei no 9.474, de 22 de julho de 1997, ou de asilo territorial. Disponível em: http://www.planalto.gov.br/ccivil_o3/_Ato2015-2018/2017/Lei/L13445.htm. Acesso em: 10 jan. 2019.

19 Artigo 120. A Política Nacional de Migrações, Refúgio e Apatridia terá a finalidade de coordenar e articular ações setoriais implementadas pelo Poder Executivo federal em regime de cooperação com os Estados, o Distrito Federal e os Municípios, com participação de organizações da sociedade civil, organismos internacionais e entidades privadas, conforme regulamento Disponível em: http://www.planalto.gov.br/ccivil_03/_Ato2015-2018/2017/Lei/L13445.htm. Acesso em: 10 jan. 2019.

20 Artigo 122. As solicitações de refúgio terão prioridade de avaliação e decisão na hipótese de existir contra o solicitante procedimento do qual possa resultar a aplicação de medida de retirada compulsória. Disponível em: http://www.planalto.gov.br/ ccivil_03/_ato2015-2018/2017/decreto/d9199.htm. Acesso em: 19 jan. 2019.

21 Artigo 181. O beneficiário de proteção ao apátrida, refúgio ou asilo político não será repatriado, deportado ou expulso enquanto houver processo de reconhecimento de sua condição pendente no País. Disponível em: http://www.planalto.gov.br/ccivil_o3/_ ato2015-2018/2017/decreto/d9199.htm. Acesso em: 19 jan. 2019. 
requisitos próprios. São diferentes formas de acolhida que podem ser aplicadas para a proteção de perseguidos, sendo o caráter humanitário inerente a ambos.

Outro traço comum entre eles é a base jurídica de cada um que é a Declaração Universal dos Direitos Humanos de 1948, bem como o império da soberania estatal que se revela decisiva para o reconhecimento do status de perseguido, tanto para o asilado quanto para o refugiado.

Quanto à concessão do asilo é predominante a discricionariedade, ante a ausência de uma regulamentação criteriosa sobre requisitos e procedimentos, exigindo-se, somente a configuração da perseguição política. Na hipótese do refúgio, há certo limite, todavia, não se pode afirmar que seja o ato vinculado, o que há é a predominância, independentemente de qualquer regulamentação, da vontade estatal como já se posicionou o Superior Tribunal de Justiça brasileiro.

Ademais, o refúgio é muito mais amplo do que o asilo, já que impõe ao Estado acolhedor a obrigação de oferecer políticas de integração local dos refugiados, bem como outras obrigações decorrentes das ratificações dos tratados internacionais.

Os instrumentos jurídicos em estudo fundam-se na solidariedade e na cooperação internacional, fato que torna evidente a proteção aos direitos humanos, universalizados pela Declaração Universal dos Direitos Humanos de 1948, bem como pelos demais tratados universais e regionais sobre o assunto, tendo como características: a universalidade, a irrenunciabilidade, a ilimitabilidade e historicidade, sendo, pois, comuns aos institutos protetivos analisados, já que estes consistem em expressão da proteção aos direitos humanos.

Ante o fato de o asilo e o refúgio serem caracterizados pela historicidade é que se reputou importante a construção histórica dos institutos, mapeando a origem de cada um deles até às recentes regulamentações, todo o esforço para averiguar a adequação dos institutos face às necessidades demandadas pelos refugiados.

O legislador pátrio atento às mudanças sociais hoje percebidas e sentidas nos diversos Estados que integram a sociedade internacional, editou a Lei no $13.445 / 17$, prevendo em seu bojo garantias, até então, não contidas na legislação brasileira. Os perseguidos, em situação de processo de concessão de acolhida em trâmite, possuem o direito de aquisição de autorização de residência temporária, alegando motivo de acolhida humanitária, garantia que viabiliza a legalidade da permanência do solicitante até que o seu status refugiado ou asilado seja reconhecido.

Outra inovação da lei é a vedação da extradição em face do solicitante de refúgio ou asilo. Pendente pedido de concessão de acolhida, a medida de cooperação não poderá ser admitida. Além disso, de acordo com a lei atual, estrangeiros sem a documentação adequada que se encontre na fronteira e que estejam em situação de refúgio, sem pátria e necessitando de ajuda humanitária serão acolhidos no Brasil, o que, anteriormente, não era possível.

A nova Lei de Migração, embora dedique poucos dispositivos acerca do asilo e refúgio, confere pontuais e importantes garantais integrando, desse modo, o sistema jurídico dos refugiados e asilados, o que confere uma harmonização entre referida normativa e os preceitos constitucionais consistentes na solidariedade e cooperação entre os povos. 


\section{REFERÊNCIAS}

ANDRADE, José Henrique Fisch de. Breve reconstituição histórica da tradição que culminou na proteção internacional dos refugiados. In: ARAÚJO, Nádia de; ALMEIDA, Guilherme Assis de (Org.). O direito internacional dos refugiados: uma perspectiva brasileira. Rio de Janeiro: Renovar, 2001.

ANNONI, Dannielle; VALDES, Lysian Carolina. Direito internacional dos refugiados e o Brasil. Curitiba: Juruá, 2013.

BARRETO, Luiz Paulo Teles Ferreira (Org.). A proteção brasileira aos refugiados e seu impacto nas Américas. 1. ed. Brasília: ACNUR, Ministério da Justiça, 2010.

BRASIL. Constituição Federal. Constituição da República Federativa do Brasil de 1988. Publicada no Diário Oficial da União, Brasília, 05 out. 1988. Disponível em: http://www. planalto.gov.br/ccivil_03/constituicao/constituicaocompilado.htm. Acesso em: 04 jan. 2019.

BRASIL, Deilton Ribeiro. As dimensões políticas, sociais e econômicas da nova lei de migração e os direitos humanos em uma sociedade globalizada. Revista Argumentum. v. 19, n. 3, 2018. p. 757-774. Disponível em: http://ojs.unimar.br/index.php/revistaargumentum/article/ view/573. Acesso em: 03 jan. 2019

BRASIL. Lei no 6.815, de 19 de agosto de 1980. Define a situação jurídica do estrangeiro no Brasil, cria o Conselho Nacional de Imigração. Publicada no Diário Oficial da União, Brasília, 21 ago. 1981. Disponível em: http://www.planalto.gov.br/ccivil_03/LEIS/L6815.htm. Acesso em: 04 jan. 2019.

BRASIL. Lei no 9.474, 22 de julho de 1997. Define mecanismos para a implementação do Estatuto dos Refugiados de 1951, e determina outras providências. Publicada no Diário Oficial da União, Brasília, 23 jul. 1997. Disponível em: http://www.planalto.gov.br/ccivil_03/ LEIS/l9474.htm. Acesso em: 04 jan. 2019.

BRASIL. Lei no 13.445, de 24 de maio de 2017. Institui a Lei de Migração. Publicado no Diário Oficial da União, Brasília, 25 maio 2017. Disponível em: http://www.planalto.gov.br/ ccivil_03/_ato2015-2018/2017/lei/L13445.htm. Acesso em o4 dez. 2017.

BRASIL. Decreto no 70.946, de o7 de agosto de 1972. Promulga o Protocolo sobre o Estatuto dos Refugiados. Publicado no Diário Oficial da União, Brasília, o8 ago. 1972. Disponível em: http://www.planalto.gov.br/ccivil_03/_ato2015-2018/2017/decreto/D9199.htm. Acesso em o4 jan. 2019.

BRASIL. Decreto no 9.199, de 20 de novembro de 2017. Regulamenta a Lei no 13.445, de 24 de maio de 2017, que institui a Lei de Migração. Publicado no Diário Oficial da União, Brasília, 21 nov. 2017. Disponível em: http://www.planalto.gov.br/ccivil_03/_ato2015-2018/2017/decreto/ D9199.htm. Acesso em 04 jan. 2019. 
BRASIL. Superior Tribunal de Justiça. Resp. no 1174235/PR. Ministro Herman Benjamin, segunda turma. Publicação DJE: 28/o2/2012, disponível em: http://portal.stf.jus.br/processos/ detalhe.asp 1174235. Acesso em: 12 jan. 2019.

COMPARATO, Fábio Konder. A afirmação histórica dos direitos humanos. 11. ed. revista e ampliada. São Paulo: Saraiva, 2017.

ONU. ACNUR. Disponível em: <http://www.acnur.org/portugues/recursos/estatisticas/ dados-sobrerefugio-no-brasil/>. Acesso em: 10 jan. 2019

ONU. Convenção relativa ao estatuto dos refugiados de 1951. Disponível em: https:// www.acnur.org/fileadmin/Documentos/portugues/BDL/Convencao_relativa_ao_Estatuto_ dos_Refugiados.pdf. Acesso em: 02 jan. 2019

ONU. Declaração universal dos direitos humanos de 1948. Disponível em: https:// declaracao1948.com.br/declaracao-universal/historia-da-declaracao-por-celso-lafer/ declaracao-universal-dos-direitos-humanos-1948. Acesso em: 10 jan. 2019.

JUBILUT, Liliana Lyra. O Direito internacional dos refugiados e sua aplicação no orçamento jurídico brasileiro. São Paulo: Método, 2007.

PEREIRA, Carolina Henriques. Refugiados da segunda guerra mundial nas Caldas da Rainha. São Paulo: Colibri, 2018.

PIOVESAN, Flávia. Direitos humanos e o direito constitucional internacional. 18. ed. São Paulo: Saraiva, 2018.

VALLADÃO, Haroldo Teixeira. Direito internacional privado. São Paulo: Freitas Bastos, 1969. 